\title{
Analysis of Intention to Buy Cinema E-Tickets Among IPB Students with Theory of Planned Behavior (TPB) Approach
}

\author{
Tria Putri Simamora ${ }^{1 *)}$, Moh Djemdjem Djamaludin ${ }^{2}$ \\ ${ }^{1,2}$ Department of Family and Consumer Sciences, Faculty of Human Ecology, IPB University, \\ Bogor 16680, West Java, Indonesia
}

*) Corresponding author: putri.tria74@gmail.com

\begin{abstract}
Internet technology has changed the way consumers buy products, one of which is the purchase of cinema tickets online (e-ticket). This study aimed to analyze of intention to purchase cinema etickets among IPB University students with the Theory of Planned Behavior (TPB) approach. This study used a cross-sectional study design and quantitative approach with online survey methods conducted at IPB campus. As many as 225 students were selected purposively as the research participant, with the criteria of undergraduate program students and had ever watched a movie at the cinema but had never bought a cinema e-ticket. The data analysis included descriptive analysis, reliability test, validity test, Spearmen correlation, and Structural Equation Model (SEM) using AMOS 21.0 and SPSS 25.0 programs. The results showed that age had a negative relationship with subjective norms, perceived behavioral control, and intention. The semester level also had a negative association with attitudes towards behavior, subjective norms, perceived behavioral control, and intention, whereas pocket money showed a negative relationship with subjective norms. The results of the analysis using SEM indicated that attitudes towards behavior, subjective norms, and perceived behavioral control had a significant positive effect on the intention to purchase cinema e-tickets. The perceived behavioral control variable had the most substantial influence on the purchase intention of cinema e-tickets, followed by subjective norms and attitudes towards behavior.
\end{abstract}

Keywords: attitudes towards behavior, intention, perceived behavior control, subjective norms, Theory of Planned Behavior (TPB)

\begin{abstract}
Abstrak
Teknologi internet telah mengubah cara konsumen dalam pembelian produk salah satunya adalah pembelian tiket bioskop secara online (e-ticket). Penelitian ini bertujuan menganalisis niat pembelian e-ticket bioskop dikalangan mahasiswa IPB dengan pendekatan Theory of Planned Behavior (TPB). Penelitian ini menggunakan desain cross-sectional study dan pendekatan kuantitatif dengan metode survey online yang dilakukan di IPB. Jumlah responden sebanyak 225 orang yang dipilih secara purposive, dengan syarat mahasiswa program Sarjana (S1) IPB yang pernah menonton bioskop namun belum pernah membeli e-ticket bioskop. Analisis yang dilakukan diantaranya analisis deskriptif, uji reliabilitas, uji validitas, uji korelasi, dan Structural Equation Modeling (SEM) menggunakan program AMOS 21.0 dan SPSS 25. Hasil penelitian menunjukkan bahwa usia memiliki hubungan negatif dengan norma subjektif, kontrol perilaku, dan niat. Tingkat semester juga memiliki hubungan negatif dengan sikap terhadap perilaku, norma subjektif, kontrol perilaku, dan niat serta uang saku memiliki hubungan negatif dengan norma subjektif. Hasil analisis menggunakan SEM menunjukkan bahwa sikap terhadap perilaku, norma subjektif dan kontrol perilaku berpengaruh positif terhadap niat beli e-ticket bioskop. Variabel kontrol perilaku memiliki pengaruh terbesar terhadap niat beli e-ticket bioskop yang diikuti oleh norma subjektif dan sikap terhadap perilaku.
\end{abstract}

Kata kunci: kontrol perilaku, niat, norma subjektif, sikap terhadap perilaku, Theory of Planned Behavior (TPB) 


\section{Introduction}

The presence of internet technology has a profound effect on human life. One impact arising from the existence of internet technology is changing the way consumers buy products and services (Sulaiman, Ng, \& Mohezar, 2008). Various conveniences offered by the Internet have made the population of internet users in Indonesia increase. The data of Internet World data (Miniwatts Marketing Group, 2019) showed that Indonesia ranked 4th in the most significant internet users in the world. Based on statistical data from the Indonesian Internet Service Providers Association (2018), internet users in Indonesia amounted to 171.17 million, jumping from 143.26 million in 2017.

The number of consumers who shop via the internet increases with the number of internet users in Indonesia. It is consistent with statistical data from the Indonesian Internet Service Providers Association (2017), which showed that 32.19\% of Indonesian people used the internet in terms of online purchases. It causes many platforms to emerge that simplifies consumers' purchase experience such as internet banking, online shopping, shipping information and ordering goods, transportation, and food purchases. The cinema ticket booking platform is of the platforms that have emerged in line with the development of internet technology. Online cinema ticket booking platforms in Indonesia include Tix-id, Cinema 21, My CGV, and GO-Tix. The presence of this platform has made it possible to purchase cinema tickets online, known as the eticketing system.

Based on data from the Statistics Indonesia (BPS) related to the creative economy sector, Indonesian cinema viewers in 2017 totalled 42.7 million people. This number increased dramatically compared to the number of cinema viewers in 2015 (16 million people). Survey data from the Indonesian Internet Service Providers Association (2016) showed 34.1 million people purchased tickets online. Compared to other online shopping transactions, e-ticketing is gaining widespread popularity because customers may obtain numerous benefits (Pramesti, 2012). Some of the benefits by purchasing cinema e-tickets are a very flexible and efficient purchasing system, and convenient purchases anywhere and anytime (Prianata et al., 2017), so consumers do not need to queue to buy cinema tickets. Also, e-ticketing makes it easier for consumers to find out the availability of tickets, available seating positions, titles and movie showtimes in theatres.

With the high level of cinema e-ticket purchases, an understanding of consumer intentions in purchasing e-tickets is needed, especially for consumers who usually do not watch at the cinema because they do not want to bother waiting in line. This research was conducted in the university student population. University students have higher education compared to other consumers, so they are considered to be more representative as the research population related to the development of communication and information technology, including e-tickets (Williamson, 2006). Besides, previous surveys prove that the majority of film viewers in Indonesia in September-October 2015 came from the age group of 19-24 years (LP3M FFTV IKJ) with the education level of college university (Ariansah, Respati, \& Wibawa, 2016).

Consumer behavior is often determined by the intentions of consumers (Sumarwan, 2014). Theory of Planned Behavior (TPB) explains that a person's intentions are influenced by attitudes towards behavior, subjective norms and control of perceived behavior (Ajzen, 2005). Research of Date et al. (2013) showed that attitudes, 
subjective norms, and perceived behavioral control influenced consumer intentions to adopt internet banking. Other studies also showed that attitudes towards behavior, subjective norms, and perceived behavioral control had a significant effect on intention (Kassem \& Lee, 2004; Ma'ruf, 2005; Haghigh et al., 2012; Farizi \& Tjahjono, 2016; Lestari et al., 2017; Ariyanto, 2018; Nugroho et al., 2018; Fikri et al., 2019; Setiawati et al., 2018). These studies used the Theory of Planned Behavior (TPB) as the analysis tool of the purchase intention. However, research on the purchase of e-tickets is still very scarce, especially in Indonesia, and no one has examined the cinema e-ticket using the Theory of Planned Behavior (TPB) approach. Research on e-ticket in Indonesia was carried out on aircraft e-ticket purchases (e.g., Andriandi \& Peniarsih, 2018). Therefore, research on the analysis of intention to purchase cinema e-tickets using the Theory of Planned Behavior (TPB) approach is essential.

Based on the explanation above, this study aims to 1) identify the social demographic characteristics of participants who have never bought a cinema e-ticket; 2) identify attitudes towards behavior, subjective norms, behavioral control, and intention to purchase cinema e-tickets; 3) analyze the relationship of participants' demographic characteristics, attitudes towards behavior, subjective norms, behavioral control, and intention to buy cinema e-tickets; 4) analyze the effect of attitudes towards behavior, subjective norms, and behavioral control on the intention to buy cinema e-tickets.

\section{Methods}

\section{Research Design}

This study used a cross-sectional study design with a quantitative approach. This study used survey techniques for data collection.

\section{Participants}

The population in this study were IPB University students. The research frame sampling consisted of IPB Bachelor Program students who had watched cinema but had never bought cinema tickets online (e-ticket). Furthermore, a sample of 225 students participated in this study. The number of samples taken was based on the SEM rule of thumb analysis, that is, the number of indicators multiplied by five (Latan, 2013).

\section{Measures}

The attitude towards behavior in this study is a positive or negative assessment of participants in buying cinema e-tickets. Attitude measurement tools used were developed from Lestari, Muflikhati, and Suharjo (2013) and Prayidyaningrum and Djamaludin (2016) consisting of twelve statements: eight behavioral belief statements and six statements of outcome evaluations with a Cronbach's Alpha value of 0.814 . Subjective norms refer to participants' perceptions that are influenced by other parties who will control the interest in buying or not buying cinema e-tickets, including family, relatives, and friends. Subjective norms are measured using six statements consisting of three normative beliefs and motivation to comply with a Cronbach's Alpha value of 0.866. Perceived behavioral control in this study is the ease or difficulty felt by participants to buy cinema e-tickets. Perceived behavioral control consists of nine statements about control beliefs and nine statements about the power of control with a 
Cronbach's Alpha value of 0.803. Cinema e-ticket purchase intentions are measured using four statement items with a Cronbach's Alpha value of 0.822 .

The assessment of attitude instruments towards behavior, subjective norms, perceived behavioral control, and intentions were rated on a scale of 1-4 (1=strongly disagree; $2=$ disagree; 3 =agree; $4=$ totally agree). The answers were then compiled by transforming the obtained value/score into an index score. Categorizing data for variables in this study consisted of high, medium, and low categories, using cut-offs which included of three types namely, low $(<33.33)$; moderate $(33.33-66.66)$; and height (> 66.66).

\section{Data Collection Technique}

The type of data used in this study was the primary data. Primary data were obtained by filling out an online questionnaire that was created using Google Form. Primary data referred to in this study included the demographic characteristics of participants, attitudes towards behavior, subjective norms, perceived behavioral control, and intention to purchase e-ticket cinema.

\section{Analysis}

Statistical analysis of this research included descriptive analysis, reliability test, validity test, correlation test, and Structural Equation Modeling (SEM). Descriptive analysis was used to identify participants' demographic characteristics, attitudes towards behavior, subjective norms, perceived behavioral control, and intentions to purchase cinema e-tickets. It includes frequency, average, standard deviation, maximum, and minimum values. Participants' answers to the measurement items on the research variables were compiled by transforming the value obtained into an index score. The index score of each study variable was then categorized as low $(<33.33)$, moderate (33.33-66.66), and high (>66.66).

Analysis using the Structural Equation Modeling (SEM) method was carried out using the Analysis of Moment Structures (AMOS) 21.0 program. The SEM was to analyze the effect of exogenous variables (independent latent variables) on endogenous variables (latent dependent). Exogenous variables in this study were attitudes towards behavior, subjective norms, and perceived behavioral control while the intention was the endogenous variable. Models produced through SEM were analyzed based on Goodness of Fit criteria (Wijayanto, 2008) as follows: Chi-Square ( $p \geq 0.05$ ), Adjusted Goodness of Fit (AGFI $\geq 0.90$ for good fit and $0.80 \leq$ AGFI $\leq 0.90$ for marginal fit), Goodness of Fit Indices (GFI $\geq 0.90$ for good fit and $0.80 \leq \mathrm{GFI} \leq 0.90$ marginal fit), Comparative Fit Index (CFI $\geq 0.90$ for good fit and $0.80 \leq \mathrm{CFI} \leq 0.90$ for marginal fit), Normed Fit Index (NFI $\geq 0.90$ for good fit and $0.80 \leq \mathrm{NFI} \leq 0.90$ for marginal fit), and Root Mean Square Error of Approximation (RMSEA $\leq 0.08$ for good fit and RMSEA $\leq$ 0.05 for close fit).

\section{Findings}

\section{Participant Characteristics}

The results showed that female participants dominated this study (71.1\%), and the rest was men (28.9\%). The age of participants was in the range of 18 to 23 years, with the largest proportion of the total participants aged 21 years $(35.1 \%)$. The amount 
of monthly allowance ranged from Rp400,000 to Rp6,500,000, with an average of Rp1,186,222.6 per month. The participant's allowance per month was dominated by less than or equal to Rp1,000,000 by (60.4\%).

There were ten faculties at IPB University. The faculty with the largest number of participants in this study was the Faculty of Human Ecology (24.5\%). On the other hand, the faculty with the smallest number of participants was the Business School $(0.4 \%)$. Also, the results of the study showed that eighth-semester students dominated $(43.6 \%)$ and the least was the tenth-semester students $(1.8 \%)$. More than half of participants reported watching a movie at the cinema one time in 3 months.

\section{Attitudes towards Behavior}

Attitudes towards behavior are determined by behavioral beliefs (namely, ideas about the consequences due to certain behaviors) and outcomes evaluation (namely, evaluations of the consequences of behavioral beliefs) (Ajzen, 2005). Based on the results of the study, the attitudes towards behavior of half of the participants were classified as moderate as many as $57.8 \%$, the remaining $4 \%$ of participants had low attitudes toward behaviors, and as many as $38.2 \%$ were classified as high attitudes towards behaviors (Table 1).

Table 1. Distribution of participants by attitudes towards behavior, subjective norms, perceived behavioral control, and intention

\begin{tabular}{|c|c|c|c|c|c|c|c|c|}
\hline \multirow{2}{*}{ Variable } & \multicolumn{2}{|c|}{ Low } & \multicolumn{2}{|c|}{ Moderate } & \multicolumn{2}{|c|}{ High } & \multirow{2}{*}{ Mean \pm SD } & \multirow{2}{*}{ Min-Max } \\
\hline & $\mathrm{n}$ & $\%$ & $\mathrm{n}$ & $\%$ & $\mathrm{n}$ & $\%$ & & \\
\hline Attitudes towards behavior & 9 & 4.0 & 130 & 57.8 & 86 & 38.2 & $61.47 \pm 16.03$ & $24.4-100$ \\
\hline Subjective norms & 53 & 23.6 & 148 & 65.8 & 24 & 10.7 & $43.9 \pm 16.6$ & $0.00-91.11$ \\
\hline $\begin{array}{l}\text { Perceived behavioral } \\
\text { control }\end{array}$ & 2 & 0.9 & 178 & 79.1 & 45 & 20.0 & $55.51 \pm 12.91$ & $29.63-94.07$ \\
\hline Intention & 3 & 1.3 & 75 & 33.3 & 147 & 65.3 & $66.74 \pm 16.67$ & $00.00-100.00$ \\
\hline
\end{tabular}

\section{Subjective Norms}

Subjective norms are participants' perceptions of the influence of others who are considered necessary in their lives that will influence their interest in buying or not buying cinema e-tickets. Ajzen (2005) explained that subjective norms could be built by normative beliefs (namely, trust in others) and motivation to comply (namely, one's desire to obey people around them). The results showed that half of the participants reported a moderate level of the subjective norm $(65.8 \%)$. The remaining was classified as low and high as many as $23.6 \%$ and $38.2 \%$, respectively. The average index score of the subjective norms showed a low result of 43.9 (Table 1).

\section{Perceived Behavioral Control}

Perceived behavioral control is the participants' perception of the ease or difficulty in buying cinema e-tickets. Ajzen (2005) explained that perceived behavioral control could be built by control beliefs (namely, several factors supporting an action/behavior) and power of control (namely, one's strength related to the factors that support the behavior). The results showed that more than half of the participants had a moderate category of perceived behavioral control that reached $79.1 \%$, as many as $0.9 \%$ was categorized low, and only $20 \%$ of a high level of perceived behavioral control. The 
average attainment of the perceived behavioral control index score was also relatively low, at 55.51 (Table 1).

\section{Purchase Intention}

The intention is the desire to buy or not buy a cinema e-ticket. More than half of participants had high-categorized intentions with a proportion of $65.3 \%$. The remaining $1.3 \%$ of participants had purchase intentions that fell into the low category, and $33.3 \%$ of participants fell into the medium category. The average intention index score was in the medium category of 66.74 (Table 1).

\section{Relationship of Participant Characteristics, Attitudes towards Behavior, Subjective Norms, Perceived Behavioral Control, and Purchase Intentions}

Table 2 shows the results of the correlation test. There was a significant negative relationship between age and subjective norms $(\mathrm{r}=-0.157 ; p<0.05)$, meaning that the older the participant, the lower the subjective norms. There was a significant negative relationship between age and behavior control $(\mathrm{r}=-0.151 ; p<0.05)$. It means that the older the participant, the lower the perceived behavioral control. Also, age had a significant negative relationship with intention $(\mathrm{r}=-0.140 ; p<0.05)$. It means that the older the participant, the lower the intention to buy cinema e-tickets.

Table 2. Correlation coefficients between participant characteristics, attitudes towards behavior, subjective norms, perceived behavioral control, and purchase intention

\begin{tabular}{lcccc}
\hline \multicolumn{1}{c}{ Variable } & $\begin{array}{c}\text { Attitudes } \\
\text { towards behavior }\end{array}$ & $\begin{array}{c}\text { Subjective } \\
\text { norms }\end{array}$ & $\begin{array}{c}\text { Perceived } \\
\text { behavioral } \\
\text { control }\end{array}$ & $\begin{array}{c}\text { Purchase } \\
\text { intention }\end{array}$ \\
\hline $\begin{array}{l}\text { Gender } \\
(0=\text { male, 1=female) }\end{array}$ & 0.057 & 0.768 & 0.388 & 0.538 \\
Age (year) & -0.062 & $-0.157^{*}$ & $-0.151^{*}$ & $-0.140^{*}$ \\
Semester level & $-0.135^{*}$ & $-0.233^{* *}$ & $-0.165^{*}$ & $-0.188^{* *}$ \\
Monthly allowance & -0.084 & $-0.138^{*}$ & 0.058 & -0.007 \\
Frequency of watching cinema & -0.056 & -0.023 & 0.068 & 0.113 \\
\hline
\end{tabular}

Note. $\left.{ }^{*}\right)$ significant at $p<0.05 ;(* *)$ significant at $p<0.01$

There was a significant negative relationship between semester levels, attitudes towards behavior $(\mathrm{r}=-0.135 ; p<0.05)$. It shows that the higher the semester level, the lower the attitude towards buying e-tickets. There was a significant negative relationship between semester level and subjective norm $(\mathrm{r}=-0.233 ; p<0.01)$, meaning that the higher the semester level, the lower the subjective norms. The semester level also had a significant negative relationship with perceived behavioral control ( $\mathrm{r}=-0.165$; $p<0.05)$. It means that the higher the semester level, the lower the perceived behavioral control. There was a significant negative relationship between semester levels and intentions to purchase cinema e-tickets $(\mathrm{r}=-0.188 ; p<0.01)$. It means that the higher the semester level, the lower the intention to buy cinema e-tickets. The allowance had a significant negative relationship with subjective norms $(\mathrm{r}=-0.138 ; p<0.05)$. It shows that the higher the allowance, the lower the subjective norm. 


\section{The Goodness of Fit Tests}

\section{Measurement Model Fit}

The measurement model shows how the manifest or observed variable represents the latent construct. The method used to test the suitability of the measurement model is the validity and reliability tests (Latan, 2013). The validity test in SEM was carried out through the average variance extracted (AVE) test by looking at the average of the variance extracted between indicators of a variable, while the reliability test was carried out through the construct reliability (CR) test by testing the reliability and consistency of the data. The results of reliability and validity testing using construct reliability (CR) and average variance extracted (AVE) tests are shown in Table 3.

Table 3. The values of construct reliability (CR) and average variance extracted (AVE)

\begin{tabular}{lcc}
\hline Latent variable & CR & AVE \\
\hline Attitudes towards behavior & 0.87 & 0.48 \\
Subjective norms & 0.95 & 0.79 \\
Behavioral control & 0.87 & 0.46 \\
Purchase intention & 0.74 & 0.42 \\
\hline
\end{tabular}

Based on the test results, subjective norms had fulfilled the reliability requirements with $\mathrm{CR}$ values greater than or equal to 0.7 and $\mathrm{AVE}$ values greater than or equal to 0.5 . This indicates that subjective norm variables had described their latent constructs well. Based on the above results, the AVE value obtained from the variables of attitudes towards behavior perceived behavioral control, and the intention was smaller than 0.5 . However, the CR value was above 0.7 . Thus the convergent validity of the latent construct was quite adequate.

\section{Overall Model Fit}

The goodness of fit for the overall model is used to examine the model appropriateness. The results of this test are declared feasible if they meet the specified criteria. Analysis of the suitability test has many criteria in which it would be better to have the model meets more than one of these criteria (Widarjono, 2010). The results of the model fit, as presented in Table 4, show that the model is already in good fit criteria, but there are some indices in marginal criteria.

Table 4. Results of the overall model fit criteria

\begin{tabular}{lccc}
\hline Goodness of fit criteria & Cut-off value & Result & Remark \\
\hline Goodness of Fit Indices (GFI) & $0.80 \leq$ GFI $\leq 0.90$ & 0.863 & marginal fit \\
Adjusted Goodness of Fit (AGFI) & $0.80 \leq$ AGFI $\leq 0.90$ & 0.831 & marginal fit \\
Comparative Fit Index (CFI) & $\geq 0.90$ & 0.924 & good fit \\
Incremental Fit Index (IFI) & $\geq 0.90$ & 0.925 & good fit \\
Normed Fit Index (NFI) & $0.80 \leq$ NFI $\leq 0.90$ & 0.847 & marginal fit \\
Root Mean Square Error of Approximation & $\leq 0.08$ & 0.060 & good fit \\
(RMSEA) & & & \\
Root Mean Square Residual (RMR) & $\leq 0.1$ & 0.056 & good fit \\
\hline
\end{tabular}

\section{Contribution of Indicators to Latent Variables}

The relationship between an indicator with its dimensions and the relationship between the indicator with its latent variable can be identified through the factor loading 
value. This value indicates the extent to which each indicator explains the dimensions as well as latent variables. The biggest factor loading value suggests that the indicator is the factor that most contributes to the formation of variables. The higher the factor loading value, the higher the contribution of the indicator to forming the variable. The contribution of each indicator with latent variables is presented in Figure in 1.

The indicator that had the greatest contribution to the latent variable attitudes towards behavior was the OE3 ("It is very important to make e-ticket purchases easy and practical") with a factor loading value of 0.77 . The indicator that had the least contribution to the variable was the OE1 ("The cinema e-ticket system will facilitate ticket purchase transactions") with a factor loading value of 0.60 . These indicators belong to the dimension of outcomes evaluation. These results indicate that the indicator OE3 explains attitudes towards behavior as many as $77 \%$, whereas the indicator OE1 explains attitudes towards behavior as many as $60 \%$.

The indicators that had the strongest and the weakest contributions in forming the subjective norm were in the dimension of the motivation to comply. The most substantial contribution was the MC2 ("I will recommend my friend buying a cinema eticket") with a factor loading value of 0.97 . The weakest indicator to explain the subjective norm was the MC1 ("I will recommend my family buying a cinema e-ticket") with a factor loading value of 0.64 .

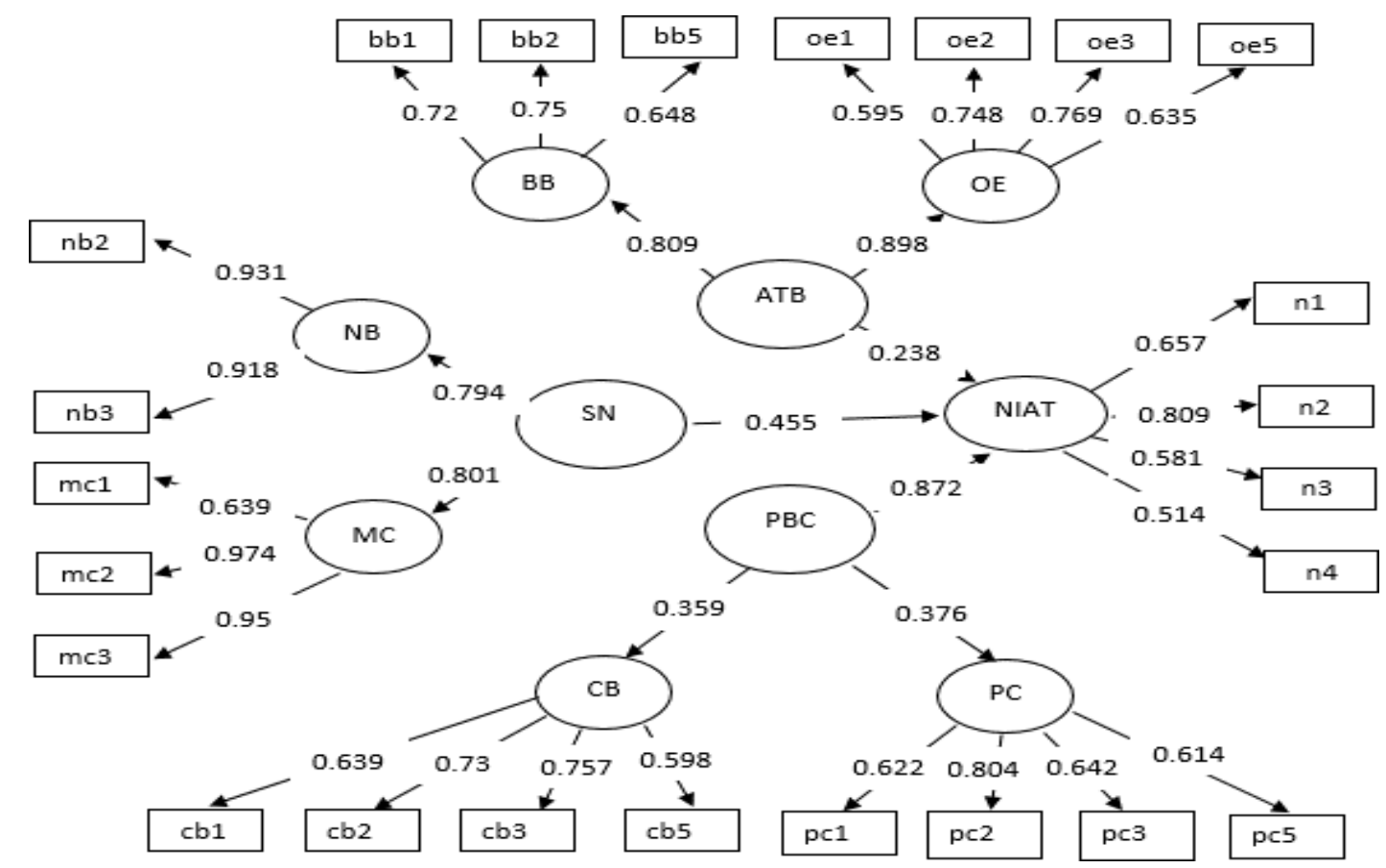

Note: $\mathrm{AB}=$ Attitudes towards behavior, $\mathrm{BB}=\mathrm{B}$ havioral belief, $\mathrm{OE}=$ Outcomes evaluation, $\mathrm{SN}=$ Subjective norm, $\mathrm{NB}=\mathrm{Normative}$ belief, $\mathrm{MC}=$ Motivation to comply, $\mathrm{PBC}=$ Perceived behavioral control, $\mathrm{CB}=$ Control belief, $\mathrm{PC}=\mathrm{Power}$ of control, NIAT=Intention

Figure 1. SEM analysis model and the value of factor loading of each indicator towards the latent variable

The indicator that had the highest contribution to the latent variable perceived behavioral control was the PC2 ("Bad image from the cinema e-ticket purchase platform 
will make me reluctant to buy a cinema e-ticket") with a factor loading value of 0.80 . The CB5 had the smallest contribution to the perceived behavioral control ("The number of e-ticket purchasing platforms makes it easy to buy a cinema e-ticket") with a factor loading value of 0.60 .

The intention consists of four statement indicators. The most substantial contribution explaining the variable was the indicator N2 ("I intend to buy a cinema eticket if I have enough money") with a factor loading value of 0.81 . The indicator that had the least contribution to the variable was the N4 ("I intend to buy a cinema e-ticket if there are discounts offered") with a factor loading value of 0.51 .

\section{Effect of Attitudes towards Behavior, Subjective Norms, and Perceived Behavioral Control on the Purchase Intention of Cinema E-tickets}

A significant effect of a variable on other variables can be seen from the p-value and critical ratio values. This study used a significance level of 0.05 (95\% confidence level). At the 0.05 significance level, the critical ratio value of each variable must be higher than 1.96. If the $\mathrm{p}$-value indicates a number smaller or equal to 0.05 and a critical ratio value higher than 1.96 , then the variable has a significant effect on another variable (Latan, 2013). Conversely, if the p-value is higher than 0.05 , and the critical ratio value is less than 1.96, the variable has no significant effects on another variable. The value of the path coefficient indicates the magnitude and direction of the effect. The effect of each variable is shown in Table 5.

Table 5. Effect of attitudes on behavior, subjective norms, perceived behavioral control on purchase intentions of cinema e-tickets

\begin{tabular}{lccc}
\hline Path & $\begin{array}{c}\text { Path } \\
\text { coefficient }\end{array}$ & Critical ratio & Remark \\
\hline Attitudes toward behavior $\rightarrow$ Intention & $\mathbf{0 . 2 3 8}^{*}$ & 3.089 & H1 accepted \\
Subjective norms $\rightarrow$ Intention & $\mathbf{0 . 4 5 5}^{*}$ & 4.955 & H2 accepted \\
Perceived behavioral control $\rightarrow$ Intention & $\mathbf{0 . 8 7 2}^{*}$ & 2.001 & H3 accepted \\
\hline
\end{tabular}

Note. (*) significant at $p<0.05$

The results of hypothesis testing showed that all hypotheses were accepted which indicated the significant influence of exogenous variables on endogenous variables. Hypothesis one showed that attitudes towards behavior had a significant positive effect on purchase intention of cinema e-tickets with a path coefficient of

0.238 . This value means that the higher the participant's attitudes towards behavior, the higher the purchase intention of cinema e-tickets. The results of the analysis on hypothesis two showed that subjective norms had a significant positive effect on the purchase intention of cinema e-tickets with a path coefficient of 0.455 . This value means that the higher the participant's social support to buy cinema e-tickets, the higher the intention to purchase cinema e-tickets. The next hypothesis showed that perceived behavioral control had a significant positive effect on the purchase intention of cinema e-tickets with a path coefficient of 0.872 . It means that the higher the participant's level of trust and strength regarding the ease of buying cinema e-tickets, the higher the purchase intention of cinema e-tickets. All hypotheses were accepted because the critical ratio value was higher than 1.96 , and the p-value was less than 0.05 . In terms of the magnitude of the influence of the three variables on the purchase intention of cinema e-tickets, perceived behavioral control showed the most substantial effect on the purchase intention of cinema e-tickets. 


\section{Discussion}

The results of this study proved that aspects that determine consumer intentions based on Theory of Planned Behavior (Ajzen, 2005), including attitudes toward behavior, subjective norms, and perceived behavioral control had a positive influence on purchase intentions of cinema e-tickets. Participants who have positive attitudes towards the purchase of cinema e-tickets, receive great encouragement from other people to make e-ticket purchases, and have positive perceptions of cinema e-ticket purchases are more likely to have high intentions to buy cinema e-tickets.

Perceived behavioral control is an individual's perception of the ease and difficulty of doing a particular behavior (Ajzen, 2005). Perceived behavioral control consists of two dimensions, namely control belief (that is, trust whether a factor can support or inhibit the purchase of cinema e-tickets) and power of control (that is, perceptions about how strongly these factors can influence the purchase of cinema etickets). The dimension that most contributed to the behavioral control variable was the power of control with a factor loading value of 0.376 . This finding is following Yasaningthias' result (2018), which stated that the dimension of the power of control had an enormous contribution in shaping perceived behavioral control compared to control belief.

The results of this study indicate that perceived behavioral control had the most considerable influence on purchase intentions of cinema e-tickets because it had the highest factor loading value. It means that perceived behavioral control provided the most considerable influence on purchase intention of cinema e-tickets compared to other variables. This finding is in line with Ariyanto's research (2018) which found that behavioral control was the most significant factor influencing repurchase intentions of e-money. Thus, perceived opportunities and available resources play a role in shaping the purchase intention of cinema e-tickets.

Perceived behavioral control illustrates participants' confidence in their ability to use the cinema e-ticketing platform. It can be shown from several statements in the questionnaire that have passed the model compatibility test. More than half of the participants had low perceived behavioral control. It means that participants are less confident and feel obstacles in buying cinema e-tickets, such as less sure that cinema etickets can be purchased anywhere, less sure of a positive image on the e-ticketing platform, less confident that a simple platform can facilitate purchasing, and less convinced that the e-ticketing platforms will make purchasing easier. The obstacle perceived by participants in purchasing cinema e-tickets is the difficulty in topping up (replenishing the balance).

Subjective norms are defined as one's view or perception that is influenced by other parties which are considered necessary in his/her life (Ajzein, 2005). Two dimensions determine subjective norms are normative belief and motivation to comply. The data analysis found that motivation to comply had the most contribution to the subjective norm. This result is not in line with the research of Yasaningthias (2018), which stated that normative beliefs contributed the most to subjective norms. The subjective norm was the variables that have the second most influence after perceived behavioral control of purchase intentions. This finding supports the research of Rustam, Widya, and Rukhviyanti (2015), which found that subjective norms were the second factor that influenced the intention to use mobile banking. 
Subjective norms can be seen from participants' perceptions of social influence or social support. Half of the participants reported low subjective norms which mean that the participants are lack of support to buy cinema e-tickets. Significant others are social figures that influence a person's decision to display or not to display a behavior (Ajzen, 2005). People who are considered to influence cinema e-ticket purchases include family, relatives, and friends. The results in this study found that friends were the social figure that most influenced participants' intention to purchase cinema etickets. Given that participants are young people who allegedly spend more time with friends and people from the same age group, friends are considered a very trustworthy figure. Thus, participants tend to consider friends' suggestions or recommedations highly.

The attitude towards behavior in this study refers to as participants' positive or negative evaluation in the purchase of cinema e-tickets. Attitudes towards behavior consist of two dimensions, that is, behavioral beliefs and outcome evaluation. This study found that the dimension that most contributed to the attitude towards behavior was the outcome evaluation. It is in accordance with Yasaningthias' research (2018) in which the outcome evaluation was more contributing to shaping the attitude towards behavior rather than behavioral belief. The attitude towards behavior was the variable showing the least influence on purchase intentions of cinema e-tickets. This finding is in line with the research by Lestari, Muflikhati, and Suharjo (2017), explaining that attitudes towards behavior had the least influence on credit card ownership intentions after perceived behavioral control and subjective norms.

More than half of the participants possessed a relatively low attitude score towards the purchase of cinema e-tickets. It means that participants do not agree that the purchase of cinema e-tickets will provide benefits and deliver participants to the expected destination. The expected objectives of participants in purchasing cinema etickets include gaining ease in ticket purchase transactions, making purchases that are easy and practical, and getting payment convenience, short lines, and time efficiency. This result is in line with Honantha (2012) who found that most consumers used etickets because it was practical, time-saving, inexpensive, and easily accessible anywhere.

Purchase intention in this study refers to the desire of participants to buy cinema e-tickets. The score of cinema e-ticket purchase intentions was in the medium category, or the participants had a reasonably good purchase intention of cinema e-tickets. Based on the participants' answers, participants intend to buy cinema e-tickets when they want to watch a movie in the future, when they have enough money and information, and if there are discounts.

The Spearman correlation test found that age had a significant negative relationship with subjective norms, behavioral control, and intention. Iy means that younger participants are more likely to possess higher subjective norms and higher intentions to buy e-ticket cinema. Aldamour et al. (2017) stated that younger consumers tended to use the latest technology and applications when ordering or buying flight tickets, while older consumers tended to use the traditional way. Also, it is essential to understand the age of consumers because each individual of a different age will use different products and services (Sumarwan, 2011). Age was negatively related to subjective norms, which means the older the participant's age, the lower the social support (subjective norms) in purchasing cinema e-tickets. It is arguably due to mature thoughts of older participants which allow them to make their own decisions, so they 
are less affected by their social environment. Fitriani, Pratiwi, and Susanto (2015) stated that the maturity level of thinking of an individual increase along with his/her age and that their comprehension and mindset will develop. Besides, Khasan (2018) also found that age influenced decision making.

The semester level had a significant negative relationship with attitudes towards behavior, subjective norms, perceived behavioral control, and intention. It means that participants in higher semester level of the university are more likely to have worse attitudes towards buying cinema e-tickets, lower subjective norms, perceived behavioral control, and purchase intention of cinema e-tickets. Participants with higher semester levels have more extensive information, so they tend to be more selective in their attitude (Setiadi, 2010). Also, people who have higher levels of education will be more careful in considering their decisions (Rita \& Kusumawati, 2011). This finding is in line with the opinion of Sumarwan (2011), which stated that a person's education level would affect their way of thinking about a problem. Khasan (2018) also found that education level influenced purchasing decisions.

Pocket money illustrates the level of ability of participants to buy goods and services. The participant's allowance had a significant negative relationship with subjective norms which means that the higher the participant's allowance, the lower the confidence in social support. One indicator of a person's social status is determined by income (Sumarwan, 2011). In this study, pocket money represents the income of participants. Participants who have a high allowance lack trust in someone who has a lower allowance. It is arguably because participants with a high allowance have a higher social status so that they may not easily receive suggestions or recommendations from others. This finding is consistent with the statement of Engel et al. (1994) that one's social status influenced one's decision making. However, the results of the study are not in line with research by Tsalitsa and Rachmansyah (2016) who found that someone who had a high income tended to follow the lifestyle of his/her social environment.

The limitation of this study is that no random sampling is taken so that this study cannot be generalized at the same population level. The characteristics of participants obtained were homogeneous so that the data collected focused on specific groups such as age, gender, and pocket money. Also, the examination of this study is limited to purchase intentions while the Theory of Planned Behavior explains the behavioral stage rather than the intention stage so this study has not thoroughly described the behavior of cinema e-ticket purchases.

\section{Conclusion and Recommendation}

\section{Conclusion}

The majority of participants in this study were female, dominated by eighthsemester students, coming from all faculties at IPB, the majority had an allowance of less than or equal to Rp1,000,000, and watched cinema once in three months. The correlation test results showed that age had a negative relationship with subjective norms, perceived behavioral control, and intention. The semester level was negatively related to attitudes towards behavior, subjective norms, perceived behavioral control, and intention, whereas pocket money had a negative relationship with subjective norms. The three aspects of Theory Planned Behavior (attitudes towards behavior, subjective norms, and perceived behavioral control) showed positive effects on the intention to purchase cinema e-tickets. The perceived behavioral control had the most impact on 
cinema e-ticket purchase intentions, followed by subjective norms and attitudes towards behavior.

\section{Recommendation}

Based on the results of the study, attitudes towards behavior, subjective norms, and perceived behavioral control positively related to the purchase intention of cinema e-tickets. Therefore, marketers need further socialization of the cinema e-ticket system to improve consumer views of the cinema e-ticketing system, especially by emphasizing the benefits of e-ticketing compared to the conventional way. Also, marketers need to enhance e-ticketing systems that make it easier for consumers in various age groups to make purchases. It is expected to increase the use of e-ticketing by different age groups to encourage young consumers who tend to be more adept at utilizing technology to recommend it to older age groups. Participants in this study have similar demographic characteristics. Therefore, future research is expected to involve more diverse participants so that the results of the study become more representative. Also, further research may include cinema e-ticket purchase behavior so that it can perfectly describe the cinema e-ticket purchase behavior using the Theory of Planned Behavior (TPB) approach.

\section{References}

Ajzen, I. (2005). Attitudes, Personality, and Behavior (Manstea T., Ed.). England: Open University Press.

Aldamour, H., Aldmour, R., Alrowwad, A., Dmour, H., Hammadan, F., Khawaldeh, \& Sufian. (2017). The effect of lifestyle on online purchasing decision for electronic services: the Jordanian flying e-tickets case. Asian Social Science, 13(11), 157-169.

Andriandi, \& Peniarsih. (2018). Analisis determinan sistem informasi e-ticketing (pendekatan extended theory of planned behaviour). JISAMAR, 2(3), 40-52.

Ariansah, M., Respati, B., \& Wibawa, B. (2016). Memahami kepenontonan film Indonesia. Imaji, 8(1), 21-34.

Ariyanto, D. (2018). Pengaruh attitude, subjective norm, dan perceived behavioral control terhadap repurchase intention e-money. Jurnal Ilmu Manajemen, 6(4), 583-389.

Date, H., Safeena, R., Hundewale, N., \& Kammani, A. (2013). Combination of TAM and TPB in Internet banking adoption. International Journal of Computer Theory and Engineering, 5(1), 146-150. http://dx.doi.org/10.7763/IJCTE.2013.V5.665.

Engel, J. F., Blackwell, R. D., \& Miniard, P. W. (1994). Perilaku Konsumen. Jakarta: Bina Rupa.

Farizi, A. S. A., \& Tjahjono, T. (2016). Persepsi pengguna transjakarta terhadap aspek amenity pada fasilitas pejalan kaki di halte dukuh atas dengan pendekatan teori perilaku terencana. Jurnal Transportasi, 16(3), 183-192.

Fikri, A., Nurmalina, R., Najib, M., Simanjuntak, M. (2019). The Determinants of Online Vegetables/Fruits Repurchase Intention: Stimulus-Organism-Response Model and Theory of Planned Behaviour. European Scientific Institute, ESI. 15 (10) : 147-167. http://dx.doi.org/10.19044/esj.2019.v15n10p147 
Fitriani, Y., Pratiwi, K., \& Susanto, A. V. (2015). Faktor-faktor yang berhubungan dengan perilaku orang tua dalam melakukan kekerasan verbal terhadap anak usia pra sekolah. Jurnal Psikologi Undip, 14(1), 81-93. https://doi.org/10.14710/jpu.14.1.81-93

Haghighi, M., Rahrovy, E., \& Vaezi, H. (2012). An application of the theory of planned behavior (TPB) in describing customers' use of cash cards in points of sale (POS). International Journal of Learning and Development, 2(6), 239-250. http://dx.doi.org/10.5296/ijld.v2i6.2985.

Honantha, C. R. (2012). Gaya hidup hijau: membeli e-ticket. Conference in Business, Accounting and Management (CBAM), 1(1), 145-150.

Indonesian Internet Service Providers Association. (2016). Penetrasi \& Profil Perialku Pengguna Internet Indonesia. Retrieved from https://apjii.or.id/downfile/file/surveipenetrasiinternet2016.pdf

Indonesian Internet Service Providers Association. (2017). Penetrasi \& Profil Perialku Pengguna Internet Indonesia. Retrieved from https://apjii.or.id/survei

Indonesian Internet Service Providers Association. (2018). Penetrasi \& Profil Perialku Pengguna Internet Indonesia. Retrieved from https://apjii.or.id/survei

Kassem, N. O., \& Lee, J. W. (2004). Understanding soft drink consumption among male adolescents using the theory of planned behavior. Journal of Behavioral Medicine, 27(3), 273-296. https://doi.org/10.1023/b:jobm.0000028499.29501.8f

Khasan, U. (2018). Analisis Faktor-faktor yang mempengaruhi perilaku konsumen dalam pengambilan keputusan pembelian White Coffee. Cakrawala, 12(2), 15761. http://dx.doi.org/10.32781/cakrawala.v12i2.271.

Latan, H. (2013). Model Persamaan Struktural: Teori dan Implementasi AMOS 21.0. Bandung: Penerbit Alfabeta.

Lestari, B. A., Muflikhati, I., \& Suharjo, B. (2017). Minat kepemilikan kartu kredit (studi kasus Kota Bogor). Jurnal Aplikasi Bisnis dan Manajemen, 3(1), 143-151. http://dx.doi.org/10.17358/JABM.3.1.143.

Ma'ruf, J. J., Mohamad, O., \& Ramayah, T. (2005). Intention to purchase via the internet: a comparison of two theoretical models. Asian Academy of Management Journal, 10(1), 79-95.

Miniwatts Marketing Group. (2018). Top 20 countries with the highest number of internet users. Retrieved from https://www.internetworldstats.com/top20.htm

Nugroho, A., Najib, M., \& Simanjuntak, M. (2018). Factors affecting consumer interest in electronic money usage with Theory of Planned Behavior (TPB). Journal of Consumer Sciences, 3(1), 15-27. https://doi.org/10.29244/jcs.3.1.15-27

Pramesti, A. (2012). Pengaruh penerapan e-ticketing terhadap loyalitas konsumen di PT Garuda (PERSERO) Tbk (Undergraduate thesis, Universitas Widyatama, Bandung, Indonesia). Retrieved from https://repository.widyatama.ac.id/xmlui/handle/123456789/3289

Prayidyaningrum, S., \& Djamaludin, M. D. (2016). Theory of planned behavior to analyze the intention to use the electronic money. Journal of Consumer Sciences, 1(2), 1-12. https://doi.org/10.29244/jcs.1.2.1-12

Prianata, R., Suprapti, N. W. S., \& Suryani, A. (2017). Implementasi technology acceptance model dalam niat membeli kembali tiket bioskop online. E-Jurnal Ekonomi dan Bisnis Universitas Udayana, 6(9), 3353-3378. 
Rita, M. R., \& Kusumawati, R. (2011). Pengaruh variabel sosio demografi dan karakteristik finansial terhadap sikap, norma subyektif dan kontrol perilaku menggunakan kartu kredit (Studi Pegawai di UKSW Salatiga). Jurnal Manajemen dan Keuangan, 9(2), 109-128.

Rustam, A., Widya, Y., \& Rukhviyanti, N. (2015). Pengaruh minat individu terhadap penggunaan mobile banking (M-banking): Model kombinasi Technology Acceptance Model (TAM) dan Theory of Planned Behavior (TPB). Jurnal Informatika dan Sistem Informasi, 7(1), 25-44.

Setiadi, N. J. (2010). Perilaku Konsumen: Perspektif Kontemporer Pada Motif, Tujuan dan Keinginan Konsumen. Jakarta: Kencana.

Setiawati, H., Hartoyo, \& Simanjuntak, M. (2018). Analysis on intention of purchasing organic foods by the undergraduate students of IPB using the Theory of Planned Behavior Approach. Jurnal Manajemen dan Agribisnis, 15(2), 198-207. https://doi.org/10.17358/jma.15.2.198

Sulaiman, A., Ng, J., \& Mohezar, S. (2008). E-ticketing as a new way of buying tickets: Malaysian perceptions. Journal of Social Sciences, 17(2), 149-157. https://doi.org/10.1080/09718923.2008.11892644

Sumarwan, U. (2011). Perilaku Konsumen. Bogor: Ghalia Indonesia.

Tsalitsa, A., \& Rachmansyah, Y. \& (2016). Analisis pengaruh literasi keuangan dan faktor demografi terhadap pengambilan kredit pada PT. Columbia cabang kudus. Media Ekonomi dan Manajemen, 31(1), 1-13. http://dx.doi.org/10.24856/mem.v31i1.280

Widarjono, A. (2010). Analisis Statistika Multivariat Terapan. Yogyakarta: Sekolah Tinggi Ilmu Manajemen YKPN.

Wijayanto, S. H. (2008). Structural Equation Modeling dengan Lisrel 8.8: Konsep dan Tutorial. Yogyakarta: Graha Ilmu.

Williamson, A. W. (2006, February 12). College students embrace the web. Retrieved from http://www.imediaconnection.com/content/8237.asp

Yasaningthias, G. (2018). Sikap penumpang Garuda Indonesia terhadap tray-set green product. Majalah Ilmiah Bijak, $15(1), \quad 1-21$. https://doi.org/10.31334/bijak.v15i1.129 